\title{
APPROACH TO RATIONAL CALCULATION OF SUPERELEVATION IN DUAL GAUGE TRACK
}

\author{
Inesa GAILIENE $\dot{E}^{\star}$, Martynas GEDAMINSKAS, Alfredas LAURINAVIČIUS \\ Dept of Roads, Vilnius Gediminas Technical University, Vilnius, Lithuania
}

Received 6 June 2016; revised 8 December 2016; accepted 4 February 2017

\begin{abstract}
One of the technical possibilities to solve a gauge crossing is to install a dual gauge. This solution has several advantages and disadvantages discussed in this paper. Lack of experience of maintenance and lack of standards for the design of dual track are among the most important disadvantages. The wheel and rail interface on track curves is more difficult than in straight sections. Therefore, the subject of the present article is a geometrical parameter of dual gauge track, i.e., the rail superelevation, which has an impact on the wheel-rail interaction at curves and influences the value of uncompensated acceleration, occurring when a train passes a curve, and, consequently, the intensity of rail wear. The objective of the present article is to analyse the features of dual gauge track and the superelevation calculation methodology considered, to present the approach to rational calculation of superelevation for dual gauge track of Šeštokai-Mockava (Lithuania-Poland) using several calculation versions as well as to make recommendations for the calculation of superelevation.
\end{abstract}

Keywords: track curve, standard gauge $(1435 \mathrm{~mm})$, Russian gauge $(1520 \mathrm{~mm})$, train speed, uncompensated lateral acceleration, wheel-rail interaction, gauge crossing.

\section{Introduction}

Because of the geometrical parameters, the moving path of wheel and the state of wheel-rail contact will change obviously, when a vehicle passes through a curved track, which can aggravate the wheel-rail interaction, intensify the wheel-rail vibration, and effect the running safety and comfort (Wang et.al 2014). It is widely known that the greater the radius of the curve rail, the less the influence on the rail wear and derailment possibilities. E.g., Wang et al. (2015) discovered that under the permitting line condition, setting up a curve radius more than 800 to improve driving stability and reduce rail wear will be more effective, compared to a small radius curve. It is stated that when the curve radius increases from $400 \mathrm{~m}$ to 800 $\mathrm{m}$, derailment coefficient is reduced by $38 \%$, rate of wheel load reduction is reduced by $41 \%$, wheel-rail lateral force is reduced by $35 \%$, and attrition power is reduced by $68 \%$. If the radius of the curve increases, all above mentioned indexes become lower, but not that substantially (Wang et al. 2015).

There are many theoretical and experimental studies on the wheel-rail interaction on the curves. There are four issues: mechanism and the calculation method of curve negotiation, the analysis and assessment of vehicle dynamic performance, the effect of vehicle parameters on dynamic performance, and the influence of railway parameters on dynamic performance (Wang et.al 2014). The effects of parameters of track structure on curving performance have been investigated by several authors. Wang specifies three main methods. The first method is a comprehensive model of vehicle system dynamics, which is used for analysing the effect of planar curve, vertical curve, and planar and vertical sections alignment on running quality of the vehicle. The second method is optimizing the design parameters of planar and vertical sections from a static point of view. Using the third method, the effects of parameters of planar and vertical sections on dynamic performance are investigated based on vehicletrack dynamic interaction (Wang et.al 2014).

The other noticeable problem in curves is the formation of Rolling Contact Fatigue (RCF) in rails. RCF is due to the combination of contact stress, tangential creep forces and creepage in the wheel-rail contact patch. Most $\mathrm{RCF}$ is found in one of two areas, on the high rail either in curved track, or in switches and crossing. The develop-

${ }^{*}$ Corresponding author. E-mail: inesa.gailiene@vgtu.lt 
ment of RCF in rails depends on the interplay between crack growth, which is governed by the contact stress and the tangential force at the contact patch, and wear, which depends on the tangential force and the creepage at the contact patch. These parameters are dependent on a large number of inter-dependents factors, in particular (Evans, Iwnicki 2002):

- curve radius;

- vehicle configuration (wheelbase, axle load, wheel diameter);

- suspension design (in particular primary yaw stiffness);

- wheel profiles (nominal profile and state of wear);

- wheel-rail friction;

- cant deficiency (depends on speed, radius and cant);

- traction and braking forces;

- track geometric quality;

- wheel and rail material properties.

We can see that many investigations of the wheel-rail interaction on curves mention the option of optimizing the design of curve parameters. We focused our own research onto uncompensated lateral acceleration in dual track gauge curves. Curves require the design of the external rail superelevation, which influences passenger ride comfort and even rail wear on curves (Sadeghi, Akbari 2006). Rail superelevation ensure that the centrifugal and centripetal forces, that occur when running in a curve, offset each other. This is difficult to achieve in mixed traffic and different train speeds. This is the reason of the occurrence of uncompensated lateral acceleration on curves. The most important impact of such acceleration is on the intensity of lateral rail wear in curves (Figure 1) (Povilaitiene 2004). Studies have shown that the rail wear intensity is minimal when uncompensated acceleration $\alpha_{a}$ is $0 \div 0.1 \mathrm{~m} / \mathrm{s}^{2}$, and the wear intensity increases when uncompensated acceleration reaches $0.5 \div 0.6 \mathrm{~m} / \mathrm{s}^{2}$. When uncompensated acceleration increases up to $0.5 \mathrm{~m} / \mathrm{s}^{2}$, the

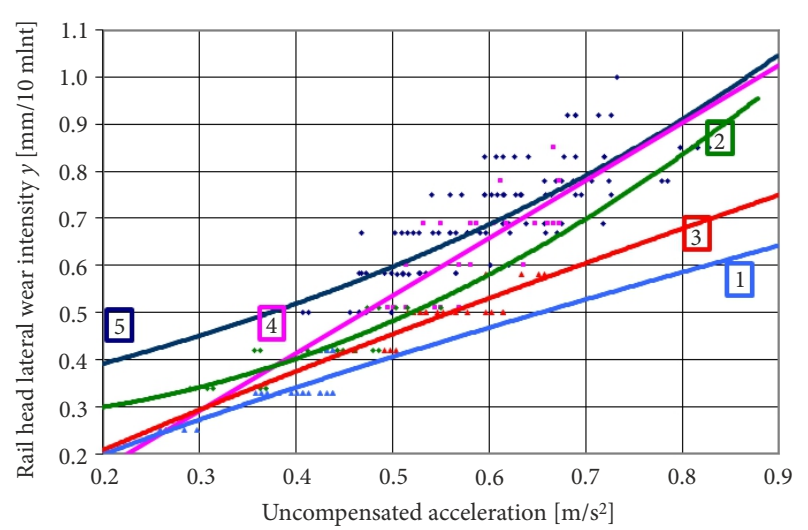

Figure 1. Dependency of rail head lateral wear intensity on the uncompensated acceleration impact on hardened rails: $1 R=650 \mathrm{~m}-y=1 /(0.148516+0.776012 / x) \cdot r=0.851$;

$2 R=700 \mathrm{~m}-y=1.22546 \cdot x-0.0773631 \cdot r=0.821$;

$3 R=900 \mathrm{~m}^{*}-y=1 /(0.271802+0.967689 / x) \cdot r=0.864$;

$4 R=900 \mathrm{~m}^{* *}-y=1 /(4.20549-4.25155 \cdot x) \cdot r=0.881$;

$5 R=1500 \mathrm{~m}-y=1 /(0.148516+0.776012 / x) \cdot r=0.851$ rail head side wear intensity increases three times. If superelevation installed is larger than the calculated one, the locomotive wheel set slides on the external rail of the curve and if the superelevation is insufficient the wheel set slides on the internal rail. When the wheels slide on internal rail the wear of external rail is smaller, however the train can derail. When the wheels slide on internal rail the wheel flange wear increases (Gailiene 2012).

All this demonstrates the importance of the correct rail superelevation calculation taking into account operational parameters of train traffic. In the case of dual gauge, the number of variables increases, therefore the task becomes even more difficult (Sadeghi, Askarinejad 2007; Cuervo et al. 2015).

In addition to a number of technical construction regulations and documents approved by the railway manager, Description of dual gauge track installation and maintenance norms (AB 'Lietuvos geležinkeliai' 2011b) and Instruction of dual gauge track installation and maintenance ( $\mathrm{AB}$ 'Lietuvos geležinkeliai' 2011a) are used for the design, construction and maintenance of dual gauge track in Lithuania. Both documents were developed based on the documents valid in Ukraine, and the requirements of both of them are mandatory for the railway staff as well as the staff of other companies, the work of which is related to the design, construction and maintenance of $1435 \mathrm{~mm}$ and $1520 \mathrm{~mm}$ dual gauge track. However, neither more detailed analysis nor adaptation was performed.

To summarize, the superelevation is an important geometrical parameter of track on curves. In this paper, we analyse the applied methodology for calculation of the superelevation and seek to identify its shortcomings. We also employ our earlier published research results (Gailienè 2012; Povilaitiené, Laurinavičius 2004; Povilaitienè 2004) to make recommendations for improvement of the methodology for calculation of the superelevation. This way we seek to make the railway traffic safer and more comfortable and to ensure the least possible wear of the rail. Therefore, we model the calculation of the superelevation on the curves of the railway section Šeštokai-Mockava (Lithuania-Poland) according to the applied methodology and corrected methodologies. We seek to determine which methodology allows to secure the lowest uncompensated lateral accelaration when the train speed is maximal, actual and lower then speed limit. The results of modelling are used for rational methodology for calculation of superelevation.

\section{Dual track gauge description}

Significant differences between the developed and developing countries can be seen in the quality and productivity of materials handling operations, the quality of transport infrastructure, the modal split as well as the problems and challenges confronted (Kovács, Spens 2006). Lithuania is aiming to integrate into the Western European railway network by developing standard gauge railway. The development of the European economy, including Lithuania, 
mainly depends on efficiency of the Europe-Asia transport system. Assurance of effective conditions for realization of international freight haulage is particularly difficult for the rail transportation, related to different gauges existing in Europe and Asia. In the territory of Asia, trains move on the Russian gauge track $(1520 \mathrm{~mm})$, encountering the standard gauge $(1435 \mathrm{~mm})$ lines in China and Korea again (Wikipedia ${ }^{\circledR}$ 2017). In Spain and Portugal, the gauge is even wider at $1668 \mathrm{~mm}$. This hinders normal flows of railway freight; obstruct passenger transportation on international routes. The majority of European countries have $1435 \mathrm{~mm}$ gauge tracks, but the railways of the Commonwealth of Independent States have $1520 \mathrm{~mm}$ gauge (Szkoda 2014a, 2014b). $1520 \mathrm{~mm}$ gauge railway also dominates in Lithuania, Latvia and Estonia. However, Lithuania's situation is unique, as its borders are not only internal ones of the European Union (with Poland and Latvia), but also external borders with Russia and Belarus (Figure 2). Thus the Lithuanian railways, due to their position, are a bridge between the Russian gauge and standard gauge railways (Wikipedia ${ }^{\circledR}$ 2017).

There are various technological and organizational solutions for the transfer of goods and passengers from one gauge to another (Szkoda 2014a, 2014b; Stukalina, Dzhaleva-Chonkova 2012):

1. Passengers have to change the train, and goods are to be reloaded. Although train changing causes additional inconveniences for passengers, but freight reloading consumes a lot of time and labor, thus raising transportation costs. It also becomes an additional risk of freight damage. In addition, one has to make sure that the rolling stock were suitable for reloading operations;

2. Bogie change. This is a technological process, when bogies of rolling stock are removed and replaced by the ones matching the gauge width. This process is also time-consuming and requires for additional technological equipment at bogie change locations;

3. Gauge change systems, which automatically switch train traffic from one gauge system to another. The gauge is changed while train passes the gauge change system. Then the wheels are unlocked, moved closer together, or further apart, and are then re-locked. This requires for special technical solutions both in rolling stock and on track (the most successful and best known systems are Talgo (Spain) and CAF dual-gauge axles (variable gauge axles) which permit through running between broad gauge and standard gauge. There are also movable wheel sets developed by German Railway and the UIC study group of gauge change wheel set including the construction of prototypes for the gauges of $1435 / 1520 \mathrm{~mm}$ and $1435 / 1668 \mathrm{~mm}$.

Gauge crossing may be solved by installing two parallel railway lines of different gauge width, or by installing dual gauge track. Dual gauge track is a track dedicated for the train traffic on different gauges. Most usually three rails are installed on dual gauge track: one is used for the traffic on both gauges, and the other two are dedicated for different gauges. However, it is not always possible to design and install such structure: in order to be able to design dual gauge track with three rails, the difference between the two gauges is to be at least as big as the width of rail foot. Otherwise, there would be no room for the installation of rail fastenings. Thus three rail track may be installed for dual gauge of $1435 \mathrm{~mm}$ and $1668 \mathrm{~mm}$ (in Spain) or of $1435 \mathrm{~mm}$ and $1067 \mathrm{~mm}$. The peculiarity of dual $1435 \mathrm{~mm}$ and $1520 \mathrm{~mm}$ gauge track is their small width difference. Considering the above gauge width difference, four-rail structure was envisaged (Figure 3).

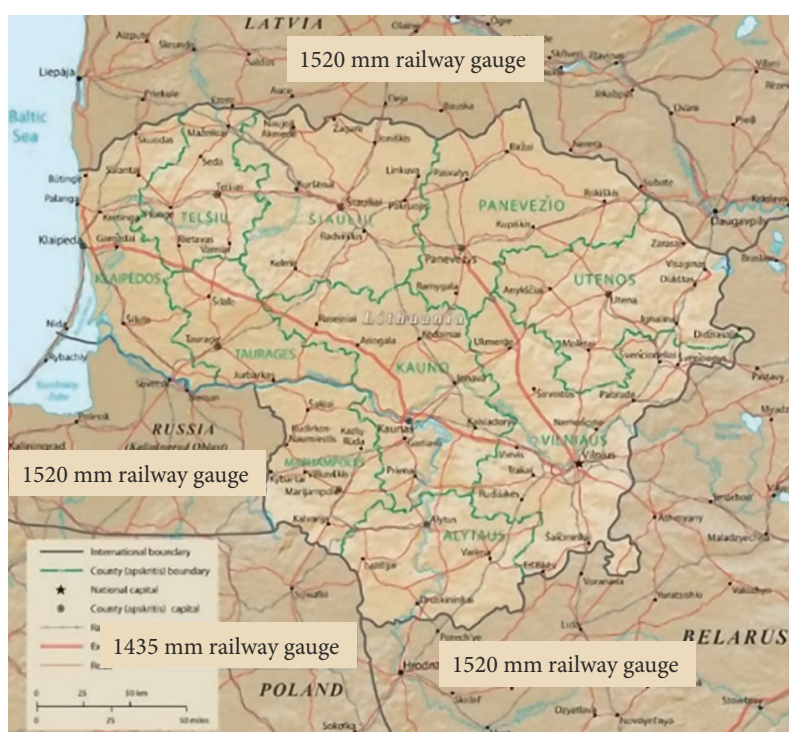

Figure 2. Map of Lithuania (Geographic Guide 2017)
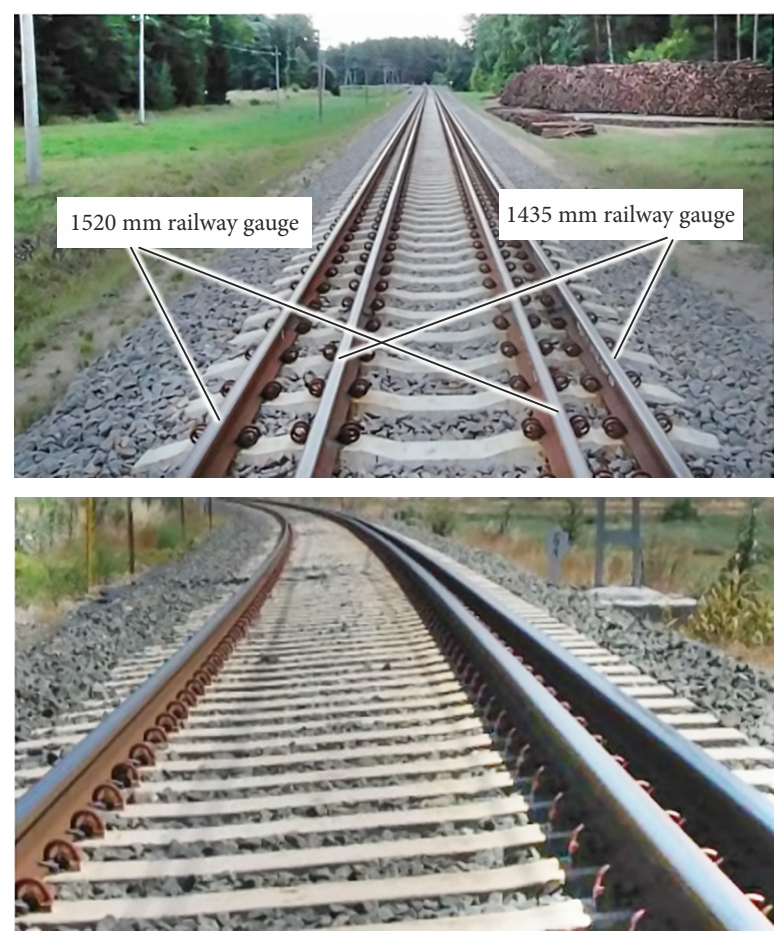

Figure 3. Structure of dual track (1435 mm and $1520 \mathrm{~mm}$ gauges) with four and three rails 
The standard gauge railway had been currently built up to Kaunas under Rail Baltica project. The total length of the line constructed is $115.2 \mathrm{~km}$, and a part of it, $5.7 \mathrm{~km}$, had been built as a dual gauge track by using four rails. Such track construction, although not unique in the world, is comparative rare phenomenon in railway infrastructure. Therefore, when deciding to design and, afterwards, to construct, maintain and renew such track, one has to solve a number of legal, technical and organizational problems. In Lithuania, instructions for the construction and maintenance of dual gauge track, based on the Ukrainian norms, were adopted (AB 'Lietuvos geležinkeliai' 2011a, 2011b). Since dual gauge still exists in Lithuania, it not only provides the possibility to ride a different gauge railway track, but it is also necessary to design, maintain and renew such track.

The operation of dual gauge track causes a number of new maintenance, repair and renewal problems for the railway manager. First of all, track machines and power tools, suitable for the work on Russian gauge track does not standard and dual gauge and vice versa. For example, Lithuania operates track diagnostic train EM-140 for the measuring of geometrical parameters, detection and evaluation of track condition. This wagon is dedicated for $1520 \mathrm{~mm}$ gauge; it neither can be used to measure the track parameters of the standard gauge nor run the standard gauge side of the dual gauge track. It is also necessary to develop or, based on the best practice of other countries, to adapt norms, descriptions, standards and rules of standard gauge maintenance and repair. These are largescale works to be, inevitably, performed.

\subsection{The specifics of dual gauge design, construction and maintenance}

Currently, in the course of the development of standard gauge Rail Baltica project, such railway had been installed from Lithuanian-Polish border up to Kaunas. Due to this project now, Lithuanian railway network has the railway of three different gauges:

- Russian gauge;

- standard gauge;

- dual gauge (1435/1520 mm).

The installation of dual gauge track is more complex than the installation of a single gauge one from the pur- chase of the track materials to the works themselves. As far as the track materials are concerned, the greatest problems are caused by longer reinforced concrete sleepers (2850 mm long), level crossing structure, crossovers and turnouts. Summing up, one can maintain that the choice of such track has more disadvantages than advantages. The summary is presented in Table 1.

\subsection{Superelevation calculation methodology and uncompensated acceleration in dual track gauges curves}

Description of dual gauge track installation and maintenance norms (AB 'Lietuvos geležinkeliai' 2011b) includes the methodology for the calculation of rail superelevation on such track.

The value of rail superelevation in curve is calculated for $1435 \mathrm{~mm}$ gauge by using formula:

$$
h_{s 1}=11.8 \cdot \frac{v_{\text {aver }}^{2}}{R}
$$

and the following formula for $1520 \mathrm{~mm}$ gauge:

$$
h_{r 1}=12.5 \cdot \frac{v_{\text {aver }}^{2}}{R},
$$

where: $h_{s 1}$ - rail superelevation for $1435 \mathrm{~mm}$ gauge [mm]; $h_{r 1}$ - rail superelevation for $1520 \mathrm{~mm}$ gauge [mm]; $v_{\text {aver }}-$ average speed $[\mathrm{km} / \mathrm{h}] ; R$ - curve radius $[\mathrm{m}]$.

Superelevation value is to be verified by using the following formula:

for $1435 \mathrm{~mm}$ gauge:

$$
h_{s 1 \min }=11.8 \cdot \frac{v_{\max }^{2}}{R}-100 ;
$$

for $1520 \mathrm{~mm}$ gauge:

$$
h_{r 1 \min }=12.5 \cdot \frac{v_{\max }^{2}}{R}-115,
$$

where: $h_{s 1 \text { min }}$ - minimum calculated rail superelevation for $1435 \mathrm{~mm}$ gauge $[\mathrm{mm}] ; h_{r 1 \text { min }}$ - minimum calculated rail superelevation for $1520 \mathrm{~mm}$ gauge $[\mathrm{mm}] ; v_{\text {max }}-$ maximum passenger train speed on curve $[\mathrm{km} / \mathrm{h}] ; 100$ and 115 - maximum height decrease value calculated by applying the set acceleration decrease norm $\left(0.7 \mathrm{~m} / \mathrm{s}^{2}\right)$ for, respectively, 1435 and $1520 \mathrm{~mm}$ track.

Table 1. Advantages and disadvantages of dual gauge track

\begin{tabular}{|l|l|}
\hline \multicolumn{1}{|c|}{ Advantages } & \multicolumn{1}{c|}{ Disadvantages } \\
\hline - land saving when available area is limited; & - the majority of permanent way materials are specific ones, therefore their avail- \\
- smaller scope of works compared with two. & ability is limited or non-existing; \\
- due to limited supply of permanent way materials the price of dual track mate- \\
rials is higher than the one of the single track materials (this is also important \\
& during operation, when spare parts are needed); \\
& - turnouts for dual gauge tracks are not produced, so the tracks are to be sepa- \\
& rated before turnouts; \\
& - track construction machines are to be fit for non-standard structural solutions; \\
& - platforms for dual gauge tracks cannot be installed at one side of such track; \\
& - lack of standard for the design of dual tracks. \\
\hline
\end{tabular}


The final rail superelevation is taken higher than obtained by using formulae (1-4). The value of the dual gauge rail superelevation is taken as equal to the calculated and accepted value of the $1520 \mathrm{~mm}$ gauge superelevation, if such value does not differ more than by $20 \%$ of that of $1435 \mathrm{~mm}$ gauge. The superelevation of the dual gauge rail shall not exceed $140 \mathrm{~mm}$. The value of the rail superelevation may be increased or decreased within the limits of $20 \%$, compared with the value obtained from the calculations, with the permission of the director of Infrastructure Operation Department of the Railway Infrastructure Directorate at JSC 'Lietuvos geležinkeliai' [Lithuanian Railways].

Uncompensated lateral acceleration is calculated as follows (Gailienè 2012):

$$
\begin{aligned}
& \alpha=\frac{v^{2}}{R} \cdot \cos \varphi-g \cdot \sin \varphi= \\
& \frac{v^{2}}{R} \cdot \cos \varphi-g \cdot \frac{h}{2 \cdot b_{0}}=\frac{v^{2}}{R}-g \cdot \frac{h}{2 \cdot b_{0}},
\end{aligned}
$$

where: $\alpha$ - uncompensated lateral acceleration $\left[\mathrm{m} / \mathrm{s}^{2}\right]$; $v$ - train speed in curve $[\mathrm{km} / \mathrm{h}] ; \varphi$ - superelevation angle; $g$ - standard gravity $\left[\mathrm{m} / \mathrm{s}^{2}\right] ; R$ - curve radius $[\mathrm{m}]$; $2 \cdot b_{0}$ - distance depending on track width $[\mathrm{m}]$ (for standard gauge $-1.5 \mathrm{~m}$, for Russian gauge $-1.6 \mathrm{~m}$ ); $h$ - actual superelevation $[\mathrm{mm}]$.

Uncompensated lateral acceleration in gauge is calculated according to the following formulae:

for $1435 \mathrm{~mm}$ gauge:

$$
\alpha_{s}=\frac{v^{2}}{3.6^{2} \cdot R}-0.00616 \cdot h ;
$$

for $1520 \mathrm{~mm}$ gauge:

$$
\alpha_{r}=\frac{v^{2}}{3.6^{2} \cdot R}-0.00613 \cdot h\left[\mathrm{~m} / \mathrm{s}^{2}\right],
$$

where: $v$ - train speed in curve $[\mathrm{km} / \mathrm{h}] ; R$ - curve radius $[\mathrm{m}] ; h$ - actual superelevation [mm].

Comparing the two formulae one may conclude that the difference obtained by using formulae (6) and (7) for the calculation of the uncompensated acceleration is not significant, therefore the following formula could be used for the calculation of uncompensated acceleration, occurred when a train runs the curve on a certain speed:

$$
\alpha=\frac{v^{2}}{3.6^{2} \cdot R}-0.00614 \cdot h .
$$

As it was mentioned above, rail wear at curves may be minimized and traffic safety ensured if the problem of superelevation calculation was solved in its complexity (in accordance with the real and maximum permissible train speeds).

In conclusion we can resume that the superelevation which gives the uncompensated lateral acceleration 0 for a given radius and given vehicle speed is called equilibrium. It is calculated using the formulae (1) and (2). However, some reasons do not allow to achieve the equilibrium: it is possible that a train stops or runs slowly in the curves.
Therefore, the maximum height of the superelevation is set (the maximum height is set because of the risk of derailment of freight trains in sharp curves due to the combined effect of high lateral and low vertical load on the outer wheel at low speed (Lindahl 2001)). It also has to be notes that not all trains have the same speed; therefore lateral acceleration is not always and not fully compensated in curves. However most investigations indicate that the lower the uncompensated lateral acceleration, the better the wheel-rail interaction and the less the rail wear. Therefore, our investigation suggests the improved methodology of calculation. Using this methodology, it is possible to calculate the superelevation on dual track gauge curves that would guarantee the lowest uncompensated lateral acceleration. Based on these assumptions we suggest three methodologies that are being used to model the calculation of the superelevation of the outer rail and to find the best solution.

Formulae (3) and (4) are included in the methodology aiming to set the requirements for the permissible uncompensated acceleration only for passenger trains, which is taken as equal to $0.7 \mathrm{~m} / \mathrm{s}^{2}$. This is a substantial drawback of the calculation methodology, as many researches had shown that setting the requirements for the permissible uncompensated acceleration of the freight trains is useful for the decrease of lateral rail wear. Whereas it is difficult to achieve the uncompensated acceleration as equal to 0 in mixed traffic due to different train speeds, it would be appropriate to set the permissible uncompensated acceleration of $\pm 0.3 \mathrm{~m} / \mathrm{s}^{2}$ for freight trains. At the same time, it would be appropriate to broaden the calculation methodology by adding the formulae setting up the uncompensated acceleration for freight trains.

\section{Superelevation calculation modelling for Šeštokai-Mockava Section}

\subsection{Description of subject of the analysis and methodology}

Eight curves of dual gauge on Šeštokai-Mockava section, having radii of $630 \div 650 \mathrm{~m}\left(R_{1}=630 \mathrm{~m}\right.$, $R_{2}=R_{3}=R_{4}=635 \mathrm{~m}, R_{5}=640 \mathrm{~m}, R_{6}=645 \mathrm{~m}$, $R_{7}=R_{8}=650 \mathrm{~m}$ ) are analysed. The permissible speed for passenger trains is $100 \mathrm{~km} / \mathrm{h}$ and $80 \mathrm{~km} / \mathrm{h}$ for freight ones. Actual speeds had been calculated by using the method developed for Russian gauge only. The following methods of the rail superelevation had had been used (the calculation methods are presented in Figure 4):

1. Superelevation calculations are performed for each curve by using current rules (formulae (1-4) (the first method in Figure 4). Having calculated and chosen the value of superelevation, one has to identify (using formula (8)) the values of uncompensated accelerations to occur when trains ran at a lowest speed to be obtained by making traction calculations (speeds 100, 80 and $40 \mathrm{~km} / \mathrm{h}$ ); 
2. Superelevation calculations are made for each curve by using improved method (the second method in Figure 4), which proposes to consider the permissible uncompensated acceleration value for freight trains $\pm 0.3 \mathrm{~m} / \mathrm{s}^{2}$ (Povilaitienè 2004). Having calculated and chosen the value of superelevation, one has to identify (using formula (8)) the values of uncompensated accelerations to occur when trains ran at a highest set speed, but if a train ran at a lowest speed to be obtained by making traction calculations (speeds 100, 80 and $40 \mathrm{~km} / \mathrm{h}$ );

3. Method, when the rail superelevation is calculated by using the third method (Figure 4) and the final choice is made taking not the biggest, but the average one. Having calculated and chosen the value of superelevation, one has to identify (using formula (8)) the values of uncompensated accelerations to occur when trains ran at a highest set speed, but if a train ran at a lowest speed to be obtained by making traction calculations (speeds 100,80 and $40 \mathrm{~km} / \mathrm{h}$ ).

The first superelevation calculation method (1) is the one included in the current rules, to be used for superelevation calculations in all dual gauge curves. Its main drawback is that it takes into consideration only the value of uncompensated acceleration for passenger trains, i.e., $0.7 \mathrm{~m} / \mathrm{s}^{2}$, but not the one of freight trains. In addition, the superelevation under such method is taken as equal to the calculated and accepted value of the $1520 \mathrm{~mm}$ gauge superelevation, if such value does not differ more than by $20 \%$ of that of $1435 \mathrm{~mm}$ gauge.

The second superelevation calculation method (2) includes not only the permissible value of the uncompensated acceleration of $0.7 \mathrm{~m} / \mathrm{s}^{2}$ for passenger trains, but also

\begin{tabular}{|c|c|}
\hline Existing superelevation calculation method & \multirow{5}{*}{$\begin{array}{l}\text { First method }(1) \\
\text { Superelevation is taken as } \\
\text { equal to the calculated and } \\
\text { accepted superelevation of } \\
1520 \mathrm{~mm} \text { gauge if it differs } \\
\text { from the one of } 1435 \mathrm{~mm} \\
\text { gauge not more than by } 20 \%\end{array}$} \\
\hline$h_{r 1}=12.5 \cdot \frac{v_{\text {aver }}^{2}}{R}$ & \\
\hline$h_{r 1 \min }=12.5 \cdot \frac{v_{\max }^{2}}{R}-115$ & \\
\hline$h_{s 1}=11.8 \cdot \frac{v_{\text {aver }}^{2}}{R}$ & \\
\hline$h_{s 1 \min }=11.8 \cdot \frac{v_{\max }^{2}}{R}-100$ & \\
\hline Improved superelevation calculation method & \\
\hline$h_{r 2}=12.5 \cdot \frac{v_{\text {aver }}^{2}}{R}$ & Second method (2) \\
\hline$h_{r 2 \min }=12.5 \cdot \frac{v_{\max }^{2}}{R}-115$ & $\begin{array}{l}\text { Superelevation taken is the } \\
\text { greatest one calculated by }\end{array}$ \\
\hline$h_{r 2 \min ^{\prime}}=12.5 \cdot \frac{v_{\max }^{2}}{R}-50$ & using formulae \\
\hline$h_{s 2}=11.8 \cdot \frac{v_{\text {aver }}^{2}}{R}$ & Third method (3) \\
\hline$h_{s 2 \min }=11.8 \cdot \frac{v_{\max }^{2}}{R}-100$ & $\begin{array}{l}\text { Superelevation taken } \\
\text { is the mean one calculated }\end{array}$ \\
\hline$h_{s 2 \min ^{\prime}}=11.8 \cdot \frac{v_{\max }^{2}}{R}-45$ & \\
\hline
\end{tabular}

Figure 4. Rail superelevation calculation methods formulae including permissible uncompensated acceleration for freight trains. It also proposes to choose the greatest superelevation off all obtained. The third calculation method (3) is the same as the second one; however, the final rail superelevation chosen is the average figures of the ones obtained supposing that this would be the optimum rail superelevation best suiting the train speeds.

\subsection{Analysis and evaluation of modelling results}

Calculation results, obtained by using three methods for rail superelevation on curves analysed, are submitted in Table 2 and shown in Figures 5 and 6.

The calculations and their analysis lead to the conclusion that the most optimum solution is to calculate the superelevation by using the second method as then the uncompensated accelerations, which occur when a train runs a curve on various speeds, are the lowest ones.

Thus, superelevation calculation method, which takes into consideration not only the permissible uncompensated acceleration for passenger trains $\left(0.7 \mathrm{~m} / \mathrm{s}^{2}\right)$, but also setting up the permissible uncompensated acceleration for freight trains $\left( \pm 0.3 \mathrm{~m} / \mathrm{s}^{2}\right)$ (Povilaitienè, Laurinavičius 2004), which is included in formulae (11) and (12), ensures that the superelevation calculated according to this method will secure the lowest uncompensated lateral acceleration.

Table 2. Results of superelevation calculations on the section analysed

\begin{tabular}{|c|c|c|c|c|}
\hline \multirow{2}{*}{ No } & \multirow{2}{*}{$\begin{array}{c}\text { Curve } \\
\text { radius } \\
{[\mathrm{m}]}\end{array}$} & \multicolumn{3}{|c|}{$\begin{array}{c}\text { Superelevation, calculated by using defined } \\
\text { method (rounded values in brackets) [mm] }\end{array}$} \\
\cline { 3 - 5 } & & $(1)$ & $(2)$ & $(3)$ \\
\hline 1 & 635 & $81.9(85)$ & $85.8(90)$ & $75.4(80)$ \\
\hline 2 & 640 & $80.3(85)$ & $84.4(85)$ & $75.5(80)$ \\
\hline 3 & 650 & $77.3(80)$ & $81.5(85)$ & $72.4(75)$ \\
\hline 4 & 639 & $80.6(85)$ & $84.7(85)$ & $76.7(80)$ \\
\hline 5 & 646 & $78.5(80)$ & $82.6(85)$ & $76.8(80)$ \\
\hline 6 & 630 & $83.4(85)$ & $87.3(90)$ & $77.6(80)$ \\
\hline 7 & 650 & $77.3(80)$ & $81.5(85)$ & $71.5(75)$ \\
\hline 8 & 635 & $81.9(85)$ & $85.8(90)$ & $75.4(80)$ \\
\hline
\end{tabular}

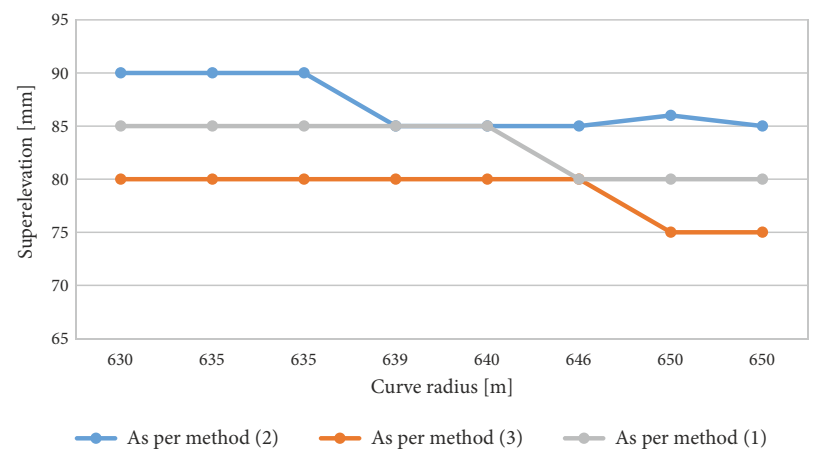

Figure 5. Calculation of superelevation by using three methods for Šeštokai-Mockava section analysed 


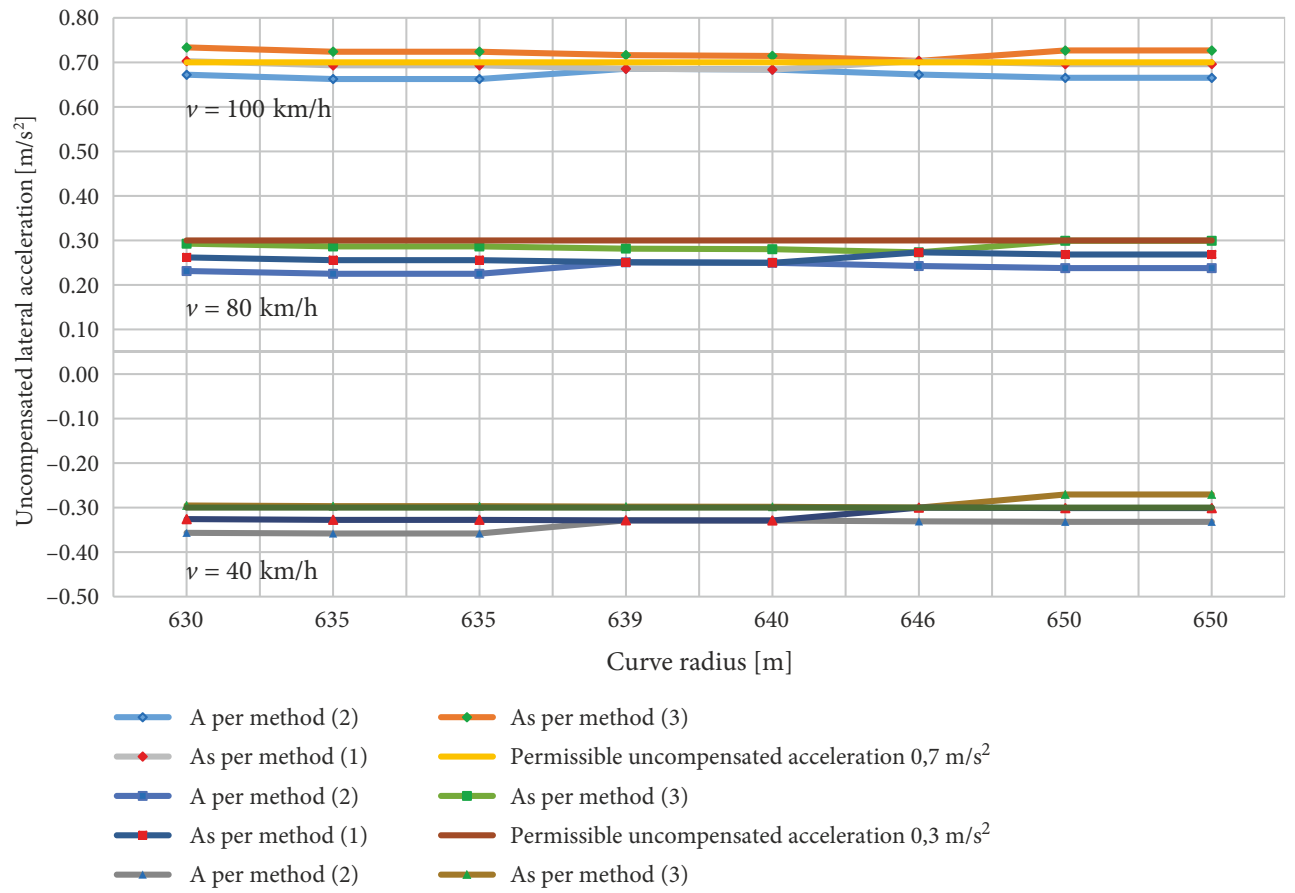

Figure 6. Dependency of uncompensated acceleration from train speed and rail superelevation

In addition, critical speed, which, if not reached, substantially worsens rolling stock running conditions on curve and increases the intensity of lateral rail wear, should be also calculated. Therefore critical speed should be included into operational requirements together with the greatest permissible train speeds. This speed is calculated by using (Gailienè 2012):

$$
v \geq \sqrt{R \cdot(h \cdot 0.08-3.89)}[\mathrm{km} / \mathrm{h}] .
$$

The final results are given in Table 3, which includes superelevations calculated, superelevation chosen, permissible uncompensated acceleration and critical speed. Taking the calculations into consideration, one can maintain that the critical speed of the section may be set as $50 \mathrm{~km} / \mathrm{h}$.

\section{Conclusions}

In this paper, we investigate the influence of geometrical parameters on the wheel-rail interface in curves. Different authors use several methods to investigate the geometrical parameters. The main issue of our article is superelevation impact on wheel-rail interaction and especially on rail wear. It is known, that balanced superelevation gives uncompensated lateral acceleration 0, but in real situation, it is not possible in many cases, especially on conventional lines with mixed (freight and passenger) trains' traffic. However, it is possible to reduce uncompensated lateral acceleration. In earlier works authors tried to investigate the above-mentioned problem on conventional track lines. This paper and investigation is focused on dual track gauge. This type of track construction is not

Table 3. Rail superelevation calculation results

\begin{tabular}{|c|c|c|c|c|c|}
\hline No & $\begin{array}{l}\text { Curve radius } \\
{[\mathrm{m}]}\end{array}$ & $\begin{array}{l}\text { Superelevation } \\
\text { chosen }[\mathrm{mm}]\end{array}$ & $\begin{array}{l}\text { Permissible value of uncompensated } \\
\text { acceleration passenger/freight }\left[\mathrm{m} / \mathrm{s}^{2}\right]\end{array}$ & $\begin{array}{l}\text { Critical (smallest) } \\
\text { train speed }[\mathrm{km} / \mathrm{h}]\end{array}$ & $\begin{array}{l}\text { Set critical train speed } \\
\text { on section }[\mathrm{km} / \mathrm{h}]\end{array}$ \\
\hline 1 & 635 & 90 & \multirow{8}{*}{0.7 and \pm 0.3} & 45.8 & 50 \\
\hline 2 & 640 & 85 & & 43.2 & 50 \\
\hline 3 & 650 & 85 & & 43.5 & 50 \\
\hline 4 & 639 & 85 & & 43.1 & 50 \\
\hline 5 & 646 & 85 & & 43.4 & 50 \\
\hline 6 & 630 & 90 & & 45.7 & 50 \\
\hline 7 & 650 & 85 & & 43.5 & 50 \\
\hline 8 & 635 & 90 & & 45.8 & 50 \\
\hline
\end{tabular}


widely investigated because it is very rare. The geometrical parameters in dual track gauge, the influence of these parameters on wheel-rail interaction, intensity of the wheel-rail vibration, and effect on the running safety and comfort is not investigated at all. Therefore it would be useful to further investigate this issue in the future, paying due attention to the complexity of the problem. In this article, we present many investigations that indicate the big influence of superelevation on rail wear. We model the calculation with the aim to use such methodology of calculation of superelevation that would allow to achieve the minimal uncompensated lateral acceleration in curves. During the modelling in dual gauge track curves we used applied methodology and alternative methodologies for calculation of superelevation. We sought to calculate the superelevation, which would take into account the permissible uncompensated acceleration for both freight and passenger trains and also the maximum permissible and actual train speeds.

Our calculations and modelling determined that the lowest uncompensated lateral acceleration is secured when the superelevation is calculated according to the second methodology of calculation and the highest value of superelevation is selected. In addition, we recommend to set the critical speed in the sections. The critical speed is the lowest train speed, which still ensures the permissible uncompensated lateral acceleration. This way it is possible to achieve the lowest intensity of the side wear of the rail and the best wheel and rail interface on curves.

\section{References}

AB 'Lietuvos geležinkeliai'. 2011a. Sugretintu vėžiu kelio tiesimo ir priežiūros instrukcija: 1435 ir $1520 \mathrm{~mm}$ pločio véžés. 255/K. AB 'Lietuvos geležinkeliai' [JSC Lithuanian Railways]. 25 p. (in Lithuanian).

AB 'Lietuvos geležinkeliai'. 2011b. Sugretintu vėžiu kelio tiesimo ir priežiūros normų aprašas: $1435 \mathrm{~mm}$ ir $1520 \mathrm{~mm}$ pločio sugretintų véžiu bei $1435 \mathrm{~mm}$ vėžès. 256/K. AB 'Lietuvos geležinkeliai' [JSC Lithuanian Railways]. 35 p. (in Lithuanian).

Cuervo, P. A; Santa, J. F; Toro, A. 2015. Correlations between wear mechanisms and rail grinding operations in a commercial railroad, Tribology International 82(B): 265-273. https://doi.org/10.1016/j.triboint.2014.06.025

Evans, J.; Iwnicki, S. D. 2002. Vehicle Dynamics and the Wheel/ Rail Interface. Rail Technology Unit, Manchester Metropolitan University, United Kingdom. 20 p.

Gailienè, I. 2012. Investigation into the calculation of superelevation defects on conventional rail lines, Transport 27(3): 229-236. https://doi.org/10.3846/16484142.2012.719198

Geographic Guide. 2017. Map of Lithuania. Available from Internet: http://www.geographicguide.net/europe/maps-europe/ lithuania.htm

Kovács, G.; Spens, K. M. 2006. Transport infrastructure in the Baltic States post-EU succession, Journal of Transport Geography 14(6): 426-436.

https://doi.org/10.1016/j.jtrangeo.2006.01.003
Lindahl, M. 2001. Track Geometry for High-Speed Railways: A Literature Survey and Simulation of Dynamic Vehicle Response. Royal Institute of Technology, Stockholm, Sweden. 160 p. Available from Internet: http://www.europakorridoren. se/spargeometri.pdf

Povilaitienè, I. 2004. Influence of Geometrical Parameters of Railway Gauge Upon Rail Durability on Curves: Summary of Doctoral Dissertation. Doctoral dissertation. Vilnius: Technika. 33 p.

Povilaitienè, I.; Laurinavičius, A. 2004. Reduction of external rail wearing on road curves, Journal of Civil Engineering and Management 10(2): 123-130.

https://doi.org/10.1080/13923730.2004.9636296

Sadeghi, J; Akbari, B. 2006. Field investigation on effects of railway track geometric parameters on rail wear, Journal of Zhejiang University - Science A 7(11): 1846-1855. https://doi.org/10.1631/jzus.2006.A1846

Sadeghi, J; Askarinejad, H. 2007. Influences of track structure, geometry and traffic parameters on railway deterioration, IJE Transactions B: Applications 20(3): 291-300.

Stukalina, O.; Dzhaleva-Chonkova, A. 2012. Problemi na zhelezop"tnite vr"zki mezhdu Ukrajna i s"sednite strani, in Nauchna konferencija 'Tehnika i stroitelni tehnologii $v$ transporta', 19-20 septemvri 2012 g., s. Ravda, B”lgarija (in Bulgarian).

Szkoda, M. 2014a. Assessment of reliability, availability and maintainability of rail gauge change systems, Eksploatacja $i$ Niezawodność - Maintenance and Reliability 16(3): 422-432.

Szkoda, M. 2014b. Life cycle cost analysis of Europe-Asia transportation systems. Technical Transactions: Mechanics - Czasopismo Techniczne: Mechanika 1-M(4): 105-114.

http://doi.org/10.4467/2353737XCT.14.053.2503

Wang, J.; Chen, X.; Li, X.; Wu, Y. 2015. Influence of heavy haul railway curve parameters on rail wear, Engineering Failure Analysis 57: 511-520.

https://doi.org/10.1016/j.engfailanal.2015.08.021

Wang, K.; Huang, C.; Zhai, W.; Liu, P.; Wang, S. 2014. Progress on wheel-rail dynamic performance of railway curve negotiation, Journal of Traffic and Transportation Engineering 1(3): 209-220. https://doi.org/10.1016/S2095-7564(15)30104-5

Wikipedia ${ }^{\oplus}$. 2017. $5 \mathrm{ft}$ and $1520 \mathrm{~mm}$ Gauge Railways. Available from Internet: https://en.wikipedia.org/wiki/5_ft_and_1520_ mm_gauge_railways 